\title{
Effect of Early Spironolactone on the ST2 Level and Clinical Changes in Acute Decompensated Heart Failure Patients
}

\author{
Trisulo Wasyanto',2), Atik Mufidah') \\ 1)Department of Cardiology and Vascular Medicine, Faculty of Medicine, \\ Universitas Sebelas Maret \\ ${ }^{2)}$ Dr. Moewardi Hospital, Surakarta
}

\begin{abstract}
Background : In spite of major advances in therapy, morbidity and mortality due to acute decompensated heart failure (ADHF) remains poor. Early initiation of mineralocorticoid antagonist (spironolactone) may increase the suppression of negative effect of renin angiotensin aldosterone system (RAAS) activation,even though it already uses ACEI/ARB accompanying ADHF and give the better outcome. This study aims todetermine the effect of early spironolactone $100 \mathrm{mg}$ a day for 3 consecutive days on the suppression of tumorigenicity 2 (ST2) level and clinical changes in patients with ADHF.

Subjects and Method: This was a randomized single blind controlled trial. Thirty eight consecutive patients with ADHF hospitalized at Dr. Moewardi Hospital, Surakarta were randomized into two groups: spironolactone group (standard therapy plus spironolactone $100 \mathrm{mg}$ per day for 3 day, $\mathrm{n}=19$ ) and control group (standard therapy, $\mathrm{n}=19$ ). Clinical sign and simptom of ADHF was monitored everyday and the difference of clinical changes was evaluated at the day-3. Venous blood samples were collected from all patients at the first day prior therapy and day- 4 after therapy. The dependent variable was ST2 level. The independent variable was Spironolacton therapy. The data were analyzed by independent t-test.

Results: Decreased levels of ST2 in the spironolactone group (mean $=36.96 ; \mathrm{SD}=21.29$ ) was higher than the control group (mean=19.73; $\mathrm{SD}=16.48)$ and it was statistically significant $(\mathrm{p}=$ o.008). Spironolacton therapy $100 \mathrm{mg}$ once daily at the first 3 day in patient with ADHF was safe, no hiperkalemia, or worsening renal function. There was decreasing risk of hipokalemia up to $33 \%$ $(\mathrm{RR}=0.33 ; 95 \% \mathrm{CI}=0.1$ to $1.0 ; \mathrm{p}=0.036)$ and greater proportion patient with improvement clinical simptom and sign of ADHF at day-3 in the spironolactone group vs control group.

Conclusion: Administration of spironolactone $100 \mathrm{mg}$ at the first 3 day plus standard therapy decreases levels of ST2, safe, decreases risk of hipokalemia and give greater proportion of clinical improvement patients $\mathrm{ADHF}$.
\end{abstract}

Keywords: Spironolactone, ADHF, ST2

\section{Correspondence:}

Trisulo Wasyanto. Department of Cardiology and Vascular Medicine, Faculty of Medicine, Universitas Sebelas Maret/Dr. Moewardi Hospital. Jl. Kol. Sutarto 132, Surakarta 57126. Indonesia. Email: trisulo.wasyanto@gmail.com.

\section{BACKGROUND}

Heart failure (HF) is still a major health problem in the world (Jessup and Brozena, 2013). The prevalence of heart failure is high, that affects more than 23 million people worldwide (Roger et al., 2004). In Indonesia, survey from Riset Kesehatan Dasar (Riskesdas) in 2013 showed that the prevalence of heart failure has been diagnosed by doctoris $0.13 \%$, and based on the doctor's diagnosis or symptoms is $0.3 \%$. Despite major advances in the treatment of heart failure, the morbidity and mortality is remains high (Burger et al., 2005). The absolute mortality rate in heart failure 
reached 50\% within 5 years of diagnosis (Levy et al., 2002; Roger et al., 2004).

The natural history of heart failure is characterized by recurrent episodes of acute heart failure (Ferreira et al., 2014). Adverse neurohormonal activation is an essential component in the pathogenesis of $\mathrm{ADHF}$. Consequently, blunting this activation is an important therapeutic goal (Burger et al., 2005). Acute heart failure (AHF) is a state of sodium and free water accumulation and inappropriate RAAS activation, which is further potentiated by decreased clearance of aldosterone (Maisel. et al., 2014).In this setting, aldosterone elevation contributes to cardiorenal dysfunction, increasing the risk of death and ventricular arrhythmias through a variety mechanism (Ferreiraet al., 2014; Albaghdadiet al., 2011). Treatment with Angiotensin Converting Enzyme Inhibitor (ACEI) or Angiotensin Receptor Blocker (ARB) is insufficient to completely suppress aldosterone activity/ aldosterone escape (Borghi et al., 1993).Early initiation of Mineralocorticoid receptor antagonists (MRAs) in addition to ACEI may attenuate the negative effects of the RAAS activation that accompanies AHF and lead to better treatment outcomes (Maisel et al., 2014). Mineralocorticoid receptor antagonists serve a dual therapeutic role by enhancing diuresis and attenuating the pathological effects of RAAS and SNS activation. Nevertheless, the potential efficacy and safety of MRAs in acute heart failure is still a question and has not been well studied (Trullas et al., 2014).

Soluble suppression of tumorigenicity 2 (sST2), usually called ST2 is a novel biomarker for neurohormonal activation in heart failure patients (Kakkar et al., 2008).The role of ST2 in heart failure has been known that as an indicator of heart muscle damage, treatment monitoring and prognosis (Sabatine et al., 2008;Bhardwaj et al., 2010).This study isevaluate the effects of MRA (spironolactone) on the clinical changes of heart failure and particularly their effect on the level of ST2.

\section{SUBJECTS AND METHOD \\ 1. Study Design \\ This was a randomized controlled trial. The study conducted in Dr. Moewardi hospital, Surakarta, Central Java, Indonesia, from October to Desember 2015.}

\section{Study Sample}

Patients were eligible for enrollment if they presented with decompensation of chronic heart failure with symptom leading to hospitalization.

Inclusion Criteria: $\mathrm{ADHF}$ patients with at least 1 symptom (dyspnea, orthopnea or edema) and 1 sign of congestion (rales on auscultation, pheripheral edema, ascites, pulmonary vascular congestion on chest radiography); age >18 years old; serum creatinine $<2.5 \mathrm{mg} / \mathrm{dL}$; serum potassium $<5 \mathrm{mg} / \mathrm{dL}$.

Exclusion Criteria: patient is suffering from infection (temperature $>37.5^{\circ} \mathrm{C}$ and or leukocytosis $>15$,00o accompanied by clinical signs of infection) and/or take oral/ intravenous antibiotics; the systolic blood pressure $\leq 100 \mathrm{mmHg}$; patients have comorbid pulmonary diseases such as Chronic Obstructive Pulmonary Disease (COPD), asthma, pneumonia and lung tumors; and history of spironolactone intolerance.

\section{Treatment Assignment}

Patients with ADHF hospitalized at Dr. Moewardi hospital Surakarta were randomized into two groups: spironolactone group and control group with simple random sampling using WinPepi software version.

\section{Trial Intervention}

ADHF patients were divided into 2 groups, who received standard therapy plus 
spironolactone $100 \mathrm{mg}$ per day for 3 days (spironolactone group) and the group that received standard therapy only (control group). Standard ADHF therapy included intravenous (i.v.) furosemide (bolus or continuous infusion), Angiotensin Converting Enzyme Inhibitor (ACEI) /Angiotensin Receptor Blocker (ARB), nitrates, digoxin and/or mechanical ventilations.

\section{Study Variables}

The dependent variable was ST2 level. The independent variable was Spironolacton therapy.

\section{Study Assessments}

Patient's clinical signs and symptoms were monitored everyday to determine the therapeutic effects. Hypotension, breast pain, muscle cramps, and other complaints may related side effects of spironolactone were also evaluated. The difference of clinical changes was evaluated at the day-3. Venous blood samples were collected from all patients at the first day prior therapy and day-4 after therapy included ureum, creatinine, electrolytes dan ST2 level.

\section{Biomarker Measurements}

Blood samples for determination of ST2 were collected at the first day prior therapy and day-4 after therapy. After centrifugation, samples were frozen at $-20^{\circ} \mathrm{C}$ until assayed in a blinded fashion in a single batch using a monoclonal sandwich ELISA (PresageTM ST2, Critical Diagnostics; San Diego, CA, USA). The lower detection limit of the assay is $2 \mathrm{ng} / \mathrm{mL}$, the upper detection limit is $200 \mathrm{ng} / \mathrm{mL}$. Age-independent reference values in a biomarker-selected healthy cohort were $3-28 \mathrm{ng} / \mathrm{mL}$ in men and 2-16 ng/mL in women (Dieplinger et al., 2009).In this study, ST2 level is analysed collaborating with the Prodia Laboratory.

\section{End Points}

Study end points included: ST2 reduction rates, proportion of patients free of congestion (no dyspnea, no orthopnea, no rales and no peripheral edema) on day 3 . Also considered safety (creatinine changes from day 1 to day 3 ) plus changes in potassium from day 1 to day 3 ).

\section{Statistical Analysis}

Data is presented in mean $\pm \mathrm{SD}$ and analyzed using SPSS 22 for windows with a $\mathrm{p}<0.05$ was considered statistically significant. To determine the mean difference between spironolactone and control groups before and after treatment, independent samples t test was used when the data were normally distributed. Mann Whitney test was used when the data were not normally distributed. To determine the mean difference between pre and post treatment in a group of paired, samples t test was used when the data were normally distributed. Wilcoxon test was used when the data were not normally distributed. If data binomial, statistical analysis was tested by Chi Square test.

\section{Research Ethics}

The Ethics Committee of Dr. Moewardi/ Medical Faculty of Sebelas Maret University in Surakarta provided ethical clearance approval for this study. All patients provided written informed consent to participate in the study.

\section{RESULTS \\ 1. Baseline Characteristics}

This study aims to determine the effect of early spironolactone therapy to the ST2 level and clinical changes in patients with ADHF. Thirty eight consecutive patients were randomized into two groups: spironolactone group (standard therapy plus spironolactone 100 mgper day for 3 day, $n=19$ ) and control group (standard therapy, $n=$ 19).

Baseline characteristics of patients in each group is shown in Table 1 . The average of age in spironolactone group (mean= 
59.53; $\mathrm{SD}=11.96)$ was higher than control group $($ mean $=52.58 ; \mathrm{SD}=16.01)$, but it was statistically not significant $(\mathrm{p}=0.138)$. The study groups were well balance in most clinical characteristics include gender, etiology of heart failure: Coronary Atherosclerotic Disease (CAD) or non-CAD, left ven-

Table 1. Baseline Characteristics

\begin{tabular}{llccc}
\hline \multirow{2}{*}{ Variables } & & $\begin{array}{c}\text { Spironolactone } \\
\text { Group n=19 }\end{array}$ & $\begin{array}{c}\text { Control Group } \\
\mathbf{n = 1 9}\end{array}$ & \multirow{2}{*}{$\mathbf{p}$} \\
\cline { 3 - 4 } & & $\begin{array}{c}\text { Mean } \pm \text { SD/ n (\%) } \\
\text { Mean } \pm \text { SD/ n(\%) }\end{array}$ & \\
\hline Age & Male & $10.53 \pm 11.96$ & $52.58 \pm 16.01$ & 0.138 \\
Sex & female & $9(47.4 \%)$ & $12(63.2 \%)$ & 0.511 \\
HF etiology & CAD & $13(68.4 \%)$ & $7(36.8 \%)$ & \\
& Non CAD & $6(31.6 \%)$ & $10(52.6 \%)$ & 0.319 \\
LVEF (\%) & & $34.53 \pm 13.44$ & $9(47.4 \%)$ & 0.810 \\
Urea (mg/dL) & & $47.21 \pm 17.23$ & $53.68 \pm 15.88$ & 0.370 \\
Creatinin (mg/dL) & & $1.16 \pm 0.21$ & $1.26 \pm 0.52$ & 0.422 \\
Potassium (mg/dL) & & $3.95 \pm 0.63$ & $4.05 \pm 0.60$ & 0.618 \\
Natrium (mg/dL) & & $135.84 \pm 4.92$ & $134.0 \pm 6.04$ & 0.310 \\
ST2 (ng/mL) & & $59.93 \pm 28.98$ & $53.88 \pm 29.25$ & 0.526 \\
History of spirono- & Yes & $8(42.1 \%)$ & $4(21.1 \%)$ & 0.163 \\
lactone therapy & No & $11(57.9 \%)$ & $15(78.9 \%)$ & \\
before admission & & & & \\
HF therapy in & Furosemide & $19(100 \%)$ & $19(100 \%)$ & 1.000 \\
hospital & ACEI/ARB & $19(100 \%)$ & $19(100 \%)$ & 1.000 \\
& Nitrate & $14(73.7 \%)$ & $12(63.2 \%)$ & 0.485 \\
& Digitalis & $4(21.1 \%)$ & $4(21.1 \%)$ & 1.000 \\
\hline
\end{tabular}

tricular ejection fraction (LVEF), ureum, creatinine, potassium and ST2 levels as well as the treatment of heart failure (furosemide, ACEI/ARB, nitrate and digitalis). Digitalis treatment in some patients in the study group was related to atrial fibrillation.

\section{The effect of early spironolactone therapy to the ST2 levels}

Prior therapy, the ST2 levels in spironolactone group was higher (mean= 59.93; $\mathrm{SD}=28.98 \mathrm{ng} / \mathrm{mL}$ ) than control group (mean $=53.88 ; \mathrm{SD}=29.25 \mathrm{ng} / \mathrm{mL})$, but it was statistically not significant $(\mathrm{p}=0.526)$. After therapy (Table 2 and Table 3), the levels of ST2 at day-4 in spironolactone group $($ mean $=21.24 ; \mathrm{SD}=21.29 \mathrm{ng} / \mathrm{mL})$ was lower than control group (mean= 34.15; $\mathrm{SD}=21.20 \mathrm{ng} / \mathrm{mL})$ and it was statistically significant $(\mathrm{p}=0.034)$.

In spironolactone group, the level of ST2 were decreased significantly from baseline $($ mean $=59.93 ; \mathrm{SD}=28.98 \mathrm{ng} / \mathrm{mL}$ prior therapy) to day -4 (mean $=21.24 ; \mathrm{SD}=$
$12.49 \mathrm{ng} / \mathrm{mL}$ ) and it was statistically significant $(\mathrm{p}<0.001)$.

In control group, the ST2 level also decreased significantly from baseline $($ mean $=53.88 ; \mathrm{SD}=29.25 \mathrm{ng} / \mathrm{mL}$ to day -4 $($ mean $=34.15 ; \mathrm{SD}=21.20 \mathrm{ng} / \mathrm{mL})$ with $\mathrm{p}<0.001$.

The reduction level of ST2 was statistically significant between spironolactone group $($ mean $=36.96 ; \mathrm{SD}=21.29 \mathrm{ng} / \mathrm{mL}$ ) and control group $($ mean $=19.73 ; \mathrm{SD}=16.48$ $\mathrm{ng} / \mathrm{mL}$ ) with $\mathrm{p}=0.008$.

\section{The effect of early spironolactone therapy to the clinical changes of ADHF}

Improvement of clinical symptoms of heart failure were observed based on anamnesis to the patient (no dispnea, no ortopnea). 
The difference of clinical symptom changes were not statistically significant between two groups ( $63.2 \%$ in spironolactone group vs $31.6 \%$, in control group, $\mathrm{p}=0.051, \mathrm{RR}$ 2.0; 95\% CI 0.95-4.22), but a greater proportion of patients in the spironolactone group was free of congestion symptoms at day-3 (12 vs 6 patients) so it was clinically significant. Improvement of clinical signs of heart failure were observed based on phy- sical examination to the patient (no rales, no pheripheral edema). The difference of clinical sign changes were not statistically significant between two groups $(73.7 \%$ in spironolactone group vs $47.4 \%$, in control group, $\mathrm{p}=0.097$, RR 1.56; 95\% CI $0.90-$ 2.68), but a greater proportion of patients in the spironolactone group was free of congestion sign at day-3 (14 vs 9 patients) so it was clinically significant (Table 4 ).

Table 2. Mean Difference of the ST2 Levels in study groups

\begin{tabular}{|c|c|c|c|c|c|c|c|c|}
\hline \multirow[t]{2}{*}{ Variable } & \multicolumn{2}{|c|}{ Spironolactone } & \multicolumn{2}{|c|}{ Control } & \multicolumn{4}{|c|}{ Mean Difference } \\
\hline & $\begin{array}{c}\text { Mean } \\
\pm \text { SD }\end{array}$ & $\begin{array}{c}\text { Median } \\
\text { (Min- } \\
\text { Max) }\end{array}$ & $\begin{array}{c}\text { Mean } \\
\pm \text { SD }\end{array}$ & $\begin{array}{c}\text { Median } \\
\text { (Min- } \\
\text { Max) } \\
\end{array}$ & $\begin{array}{l}\text { Mean } \\
\text { Diffe- } \\
\text { rence }\end{array}$ & SE & $\mathbf{p}$ & $\begin{array}{c}\text { 95\% CI } \\
\text { (Lower- } \\
\text { Upper) } \\
\end{array}$ \\
\hline $\begin{array}{l}\mathrm{ST} 2 \text { prior } \\
\text { treatment } \\
(\mathrm{ng} / \mathrm{mL})\end{array}$ & $\begin{array}{c}59.93 \pm \\
28.98\end{array}$ & $\begin{array}{c}58.36(13.72 \\
-107.94)\end{array}$ & $\begin{array}{c}53.88 \pm \\
29.25\end{array}$ & $\begin{array}{c}46.11 \\
(13.08- \\
100.53)\end{array}$ & 6.05 & 9.45 & 0.526 & $\begin{array}{l}13.11- \\
25.21\end{array}$ \\
\hline $\begin{array}{l}\text { ST2 after } \\
\text { treatment } \\
(\mathrm{ng} / \mathrm{mL})\end{array}$ & $\begin{array}{c}21.24 \pm \\
21.29\end{array}$ & $\begin{array}{c}15.86\left(7.15^{-}\right. \\
51.55)\end{array}$ & $\begin{array}{c}34.15 \pm \\
21.10\end{array}$ & $\begin{array}{c}30.08(11.17 \\
-77.60)\end{array}$ & 12.91 & 8.71 & 0.034 & $7.15-77.60$ \\
\hline Delta ST2 & $\begin{array}{c}36.96 \pm \\
21.29\end{array}$ & $\begin{array}{c}15.04(1.51 \\
-49.70)\end{array}$ & $\begin{array}{c}19.73 \pm \\
16.48\end{array}$ & $\begin{array}{c}41.04(3.01- \\
67.06)\end{array}$ & 17.23 & 6.17 & 0.008 & $\begin{array}{l}4.70- \\
29.75\end{array}$ \\
\hline
\end{tabular}

Table 3. ST2 level prior and after treatment between two groups

\begin{tabular}{|c|c|c|c|c|c|c|c|c|}
\hline \multirow[b]{2}{*}{ Variable } & \multicolumn{2}{|c|}{ Prior Treatment } & \multicolumn{2}{|c|}{ After treatment } & \multicolumn{4}{|c|}{ Mean difference } \\
\hline & $\begin{array}{c}\text { Mean } \\
\pm \text { SD }\end{array}$ & $\begin{array}{c}\text { Median } \\
\text { (Min- } \\
\text { Max) }\end{array}$ & $\begin{array}{c}\text { Mean } \\
\pm \text { SD }\end{array}$ & $\begin{array}{c}\text { Median } \\
\text { (Min- } \\
\text { Max) }\end{array}$ & $\begin{array}{l}\text { Mean } \\
\text { Diffe- } \\
\text { rence }\end{array}$ & SE & $\mathbf{p}$ & $\begin{array}{l}\text { 95\% CI } \\
\text { Lower- } \\
\text { Upper }\end{array}$ \\
\hline $\begin{array}{l}\text { ST2 level in } \\
\text { Spironolactone } \\
\text { group (ng/mL) }\end{array}$ & $\begin{array}{c}59.93 \pm \\
28.98\end{array}$ & $\begin{array}{c}58.36\left(13.7^{-}\right. \\
107.9)\end{array}$ & $\begin{array}{c}21.24 \\
\pm \\
12.49\end{array}$ & $\begin{array}{c}15.86(7.2- \\
51.6)\end{array}$ & 38.69 & 7.24 & $<0.001$ & $\begin{array}{l}24.01- \\
53.38\end{array}$ \\
\hline $\begin{array}{l}\text { ST2 level in } \\
\text { control group } \\
\text { (ng/mL) }\end{array}$ & $\begin{array}{c}53.88 \pm \\
29.25\end{array}$ & $\begin{array}{c}46.11\left(13.10^{-}\right. \\
100.50)\end{array}$ & $\begin{array}{c}34.15 \\
\pm \\
21.20\end{array}$ & $\begin{array}{l}30,08 \\
(11.17- \\
77.60)\end{array}$ & 19.73 & 8.05 & $<0.001$ & $\begin{array}{l}11.2- \\
100.5\end{array}$ \\
\hline
\end{tabular}

Worsening renal function (increase in $\mathrm{Cr}$ $\geq 0.3 \mathrm{mg} / \mathrm{dL}$ or eGFR decline $>25 \%$ from baseline) was observed in control group (1 patient), but none in spironolactone group $(5.3 \%$ vs $0 \%, p=0.311)$. Serum potassium $(\mathrm{K}+)$ levels did not differ significantly between groups and no patient developed hyperkalemia (serum $\mathrm{K}+\geq 5.5 \mathrm{mg} / \mathrm{dL}$ ). Hypokalemia (serum $\mathrm{K}+\leq 3.5 \mathrm{mg} / \mathrm{dL}$ ) was less frequent in spironolactone group $(15.8 \%$ vs $47.4 \%)$ and statistically significant ( $\mathrm{p}=0.036$, RR 0.33 ; 95\% CI 0.1-1.0). It means that an additional early spironolactone therapy in patients with ADHF will reduce the relative risk for hypokalemia by $33 \%$ compared to the control group (see Table 5). 
Table 4. Side Effects of ADHF treatments

\begin{tabular}{|c|c|c|c|c|c|}
\hline \multirow[t]{2}{*}{ Variable } & \multicolumn{2}{|c|}{ Side Effects } & \multirow[t]{2}{*}{$\mathbf{p}$} & \multicolumn{2}{|c|}{ Risk Estimation } \\
\hline & Yes & No & & $\mathbf{R R}$ & (95\% CI) \\
\hline \multicolumn{6}{|l|}{ Hypokalemia } \\
\hline \multicolumn{6}{|c|}{ Spironolactone group } \\
\hline Number & 3 & 16 & & & \\
\hline$\%$ in group & $15.8 \%$ & $84.2 \%$ & & & \\
\hline Control group & & & 0.036 & 0.33 & $0.1-1.0$ \\
\hline Number & 9 & 10 & & & \\
\hline$\%$ in group & $47.4 \%$ & $52.6 \%$ & & & \\
\hline \multicolumn{6}{|c|}{$\begin{array}{l}\text { Worsening renal } \\
\text { function }\end{array}$} \\
\hline \multicolumn{6}{|c|}{ Spironolactone group } \\
\hline Number & $\mathrm{O}$ & 19 & 0.311 & 1.056 & $0.949-1.174$ \\
\hline$\%$ in group & $0 \%$ & $100 \%$ & & & \\
\hline \multicolumn{6}{|l|}{ Control group } \\
\hline Number & 1 & 18 & & & \\
\hline$\%$ in group & $5.3 \%$ & $94.7 \%$ & & & \\
\hline
\end{tabular}

Table 5.Changes in clinical signs and symptom at day-3

\begin{tabular}{|c|c|c|c|c|c|}
\hline \multirow[t]{2}{*}{ Variable } & \multicolumn{2}{|c|}{ Free of congestion at day-3 } & \multirow[t]{2}{*}{$\mathbf{p}$} & \multicolumn{2}{|c|}{ Risk Estimation } \\
\hline & Yes & No & & $\mathbf{R R}$ & CI 95\% \\
\hline \multicolumn{6}{|l|}{ Symptom of HF } \\
\hline \multicolumn{6}{|c|}{ Spironolactone group } \\
\hline Number & 12 & 7 & \multirow{5}{*}{0.051} & \multirow{5}{*}{2.0} & \multirow{5}{*}{$0.95-4.22$} \\
\hline$\%$ in group & $63.2 \%$ & $36.8 \%$ & & & \\
\hline Control group & & & & & \\
\hline Number & 6 & 13 & & & \\
\hline$\%$ in group & $31.6 \%$ & $68.4 \%$ & & & \\
\hline \multicolumn{6}{|l|}{ Sign of HF } \\
\hline \multicolumn{6}{|c|}{ Spironolactone group } \\
\hline Number & 14 & 5 & & \multirow{5}{*}{1.56} & \multirow{5}{*}{$0.90-2.68$} \\
\hline$\%$ in group & $73 \cdot 7 \%$ & $26.3 \%$ & \multirow{4}{*}{0.097} & & \\
\hline Control group & & & & & \\
\hline Number & 9 & 10 & & & \\
\hline$\%$ in group & $47.4 \%$ & $52.6 \%$ & & & \\
\hline
\end{tabular}

\section{DISCUSSION}

The management of Acute Decompensated Heart Failure (ADHF) iniatialy focuses on life threathening reversible precipitants, and therapeutic fluid removal to relieve congestion, optimize cardiac function and minimize end-organ damage (Gheorghiade et al., 2009).Importantly, aldosterone levels are elevated in ADHF despite therapy with ACEI/ARB and beta blockers, and Mineral- ocorticoid receptor (MR) activation may contribute to both acute decompensation (i.e. fluid retention and vasoconstriction) and progressive cardiorenal dysfunction (i.e. fibrosis, inflammation, oxidative stress and hypertrophy) in patient with heart failure (HF) (Struthers et al., 2008). The use of Mineralocorticoid Receptor Antagonist (MRA) in AHF may be a key therapeutic intervention in patiens with worsen- 
ing $\mathrm{HF}$ by virtue of their ability to augment diuresis and attenuate the pathological effects of MR activation (Struthers et al., 2002; Albaghdadi et al., 2011).

This study was a experimental, single blind randomized controlled trial that evaluate the effects of early administration of $100 \mathrm{mg}$ per day spironolactone to standard therapy on the clinical changes of $\mathrm{HF}$ and particularly their effect on levels of ST2 in patient with ADHF.ST2 is a biomarker for neurohormonal activation in $\mathrm{HF}$ patients and serve as indicators of cardiac muscle damage, treatment monitoring and prognosis (Kakkar et al., 2008; Sabatine et al., 2008). The results showed that after treatment, the levels of ST2 at day-4 were decreased significantly from baseline in two groups, but the decreasing ST2 levelswere more pronounced in spironolactone group than control group. There was also a significant different of delta ST2 between two groups $(36.96 \pm 21.29 \mathrm{ng} / \mathrm{mL}$ inspironolactone group vs $19.73 \pm 16.48 \mathrm{ng} / \mathrm{mL}$ in control group, $\mathrm{p}=0.008)$. The effects of early spironolactone therapy on the ST2 levels in ADHF patients have not been studied before. Research by Lax et al, that evaluate the effects of MRAs (eplerenone and spironolactone) in animal models of myocardial infarction and Left Ventricle (LV) disfunction by permanent ligation of anterior coronary artery in 45 male Wistar rats, showed that treatment with MRAs down regulated Galectin-3 (Gal-3) and Tranforming Growth Factor Beta (TGF- $\beta$ ), and enhanced Interleukin 33 (IL33/ST2) signaling with lower expression SST2. Modulation of Gal-3 and IL33/ST2 induced by MRA correlated withlower expression levels of fibrosis and inflammation marker (Collagen types I and III, IL-6,TNF- $\alpha$ and MCP1). There was no difference between eplerenone or spironolactone groups (Lax et al., 2015).
The difference in changes of clinical signs and symptoms of ADHF were not statistically significant in the spironolactone group and the control group, but the proportion of clinical signs and symptoms improvement was greater in patients with spironolactone group than the control group (clinically significant). The previous study by Ferreira et al., whoevaluated the effects of spironolactone in patients with ADHF by examining N Terminal-pro Natriuretuc Peptide (NT-proBNP) levels and clinical changes ofHF, adding spironolactone 50-100 mg plus standard therapy, and concluded that early administration of spironolactone was safe, associated with earlier resolution of symptoms and signs of congestion as well as a more pronounced NT-proBNP reduction (Ferreira et al., 2014).

Providing diuresis while minimizing cardiorenal injury through exacerbation of neurohormonal and inflammatory pathways is important in AHF therapy. Agressive use of loop diuretics are the mainstay of early therapy in AHF, and are effective in reducing cardiac filling pressures and alleviating symptomatic congestion. However, loop diuretic induced natriuresis and diuresis are often associated with further neurohormonal activation electrolyte abnormalities and worsening renal function (Hasselblad et al., 2007; Domanski et al., 2003). Loop diureticmediated increased in distal tubular sodium delivery lead to tubular hypertrophy and hyperplasia. Increased tubular sodium $\left(\mathrm{Na}^{+}\right)$also contributes to elevated renin-angiotensin-aldosteronesystem and sympathetic nervous system activity and ultimately elevated levels of aldosterone leading to up-regulated sodium channelsin the distal tubule. The structural and functional alterations that result from elevated tubular sodium delivery contribute to 
diureticresistance, in part, due to renal and neurohumoral responses to increased proximal $\mathrm{Na}^{+}$. Mineralocorticoid receptor antagonists act at thesedistal tubular sites and to augment natriuresis in the diuretic resistant and excess fluidin AHF patients (Domansk et al., 2011).

The concern about excessive hyperkalemia prevent the prescription of MRAs in many clinical setting (Sanjay et al., 2008). This study showed that early administration of spironolactone are relatively safe, there was no evidence of hyperkalemia or worsening renal function in spironolactone group, while in control group there was 1 incident of worsening kidney function without incidence of hyperkalemia. The concomitant use of i.v. diuretics with kaliuretic properties could contributed to the absent of hyperkalemia. On the other hand, a significant difference of the incidence of hypokalemia was observed in spironolactone group and control group (15.8\% vs 47.4\%, $\mathrm{p}=0.036)$, it showed that early spironolactone therapy can reduce the risk of hypokalemia up to $33 \%(\mathrm{RR}=0.33 ; 95 \%$ CI 0.1-1.0). Spironolactone is a potassiumsparing diuretics, which can reduce the risk of hypokalemia due to the use of furosemide and potassium excretion as a result increased aldosterone levels (Ferreira et al., 2014).

Administration of spironolactone 100 mg at the first 3 day plus standard therapy in patients with ADHF decreases levels of ST2, decreases risk of hypocalemic, and give greater proportion of clinical improvement compared with standard therapy only. Early spironolactone therapy in ADHF may improve congestion through diuretic effect and prevention of neurohormonal activation, that showed with an early resolution of the congestive signs and simptoms and a more pronounced ST2 level reduction.

\section{AUTHOR CONTRIBUTIONS}

Trisulo Wasyanto and Atik Mufidah collected the data, measured suppression of tumorigenicity 2 (ST2) level, examined clinical changes, did data analysis, and wrote the manuscript.

\section{CONFLICT OF INTEREST}

The authors declare there is no conflict of interest.

\section{ACKNOWLEDMENT}

We would like to thank Dr. Moewardi Hospital that give permission to collect the data.

\section{FUNDING AND SPONSORSHIP}

No external funding and sponsorship.

\section{REFERENCE}

Albaghdadi M, Gheorghiade M, Pitt B (2011). Mineralocorticoid receptor antagonism: therapeutic potential in acute heart failure syndromes. Eur Heart J. 32: 2626-33.

Badan Penelitian dan Pengembangan Kesehatan Departemen Kesehatan Republik Indonesia (2013). Laporan Nasional Riset Kesehatan Dasar (Riskesdas) Jakarta: Departemen Kesehatan Republik Indonesia.

Bhardwaj A, Januzzi JL (2010). ST2: A novel biomarker for heart failure. Expert Rev Mol Diagn. 10: 459-64.

Borghi C, Boschi S, Ambrosioni E et al. (1993). Evidence of a partial escape of renin-angiotensin-aldosterone blockade in patients with acute myocardial infarction treated with ACE inhibitors. J Clin Pharmacol. 33:40-5.

Burger AJ (2005). A Review of the Renal and Neurohormonal Effect of B-Type Natriuretic Peptide. CHF. 11:30-8. 
Dieplinger B, Januzzi JL, Steinmeir M et al. (2009). Analytical and clinical evaluation of novel high-sensitivity assay for measurement of soluble ST2 in human plasma-the Presage ST2 assay. Clin Chim Acta. 409: 33-40.

Domanski M, Norman J, Pitt B, et al. (2003). Diuretic use, progressive heart failure, and death in patients in the Studies of Left Ventricular Dysfunction (SOLVD). J Am Coll Cardiol. 42: 705-8.

Ferreira JP, Santos M, Almeida S, et al. (2014). Mineralocorticoid receptor antagonism in acutely decompensated chronic heart failure. Eur $\mathrm{J}$ Intern Med. 25: 67-72.

Gheorghiade M, Pang PS (2009). Acute heart failure syndrome. $\mathrm{J}$ Am Coll Cardiol. 3: 557-73.

Hasselblad V, Stough WG, Shah MR, et al. (2007). Relation between dose of loop diuretics and outcomes in a heart failure population: results of the ESCAPE trial. Eur J Heart Fail. 9: 1064-9.

Jessup M, Brozena S (2013). Heart failure. N Engl J Med. 348:2007-18.

Kakkar L, Lee RT (2008). The IL-33/ST2 pathway: therapeutic target and novel biomarker. Nat Rev Drug Disc. 7(10): 827-40.

Lax A, Sanchez-Mas J, Lopez AM, et al. (2015). Mineralocorticoid Receptor Antagonists Modulate Galectin-3 and Interleukin-33/ST2 Signaling in Left Ventricular Systolic Dysfunction After
Acute Myocardial Infarction. J Am Coll Cardiol HF. 3:50-8.

Levy D, Kenchaiah S, Larson MG, et al. (2002). Long-term trends in the incidence of and survival with heart failure. N Eng J Med. 347:1397-402.

Maisel A, Xue Y, Van Veldhuisen DJ, et al. (2014). Effect of spironolactone on 30-day death and heart failure rehospitalization (from the $\mathrm{COACH}$ Study). Am J Cardiol; 114:737-42.

Roger VL, Weston SA, Redfield MM, et al. (2004). Trends in heart failure incidence and survival in a communitybased population. JAMA. 292:344-50.

Sabatine MS, Morrow DA, Higgins LJ, et al. (2008). Complementary roles for biomarkers of biomechanical strain ST2 and N-terminal prohormone B-type natriuretic peptide in patients with ST-elevation myocardial infarction. Circulation; 117:1936-44.

Sanjay S, Annigeri RA, Seshadri R, et al. (2008). The comparison of the diuretic and natriuretic efficacy of continuous and bolus intravenous furosemide in patient with chronic kidney disease. Nephrology. 13 (3): 247-50.

Struthers A, Krum H, Williams G (2008). A comparison of the aldosterone blocking agents epleronone and spironolactone. Clin Cardiol. 31: 153-8.

Struthers A (2002). Aldosterone: cardiovascular assault. Am Heart J. 144 (5): S27.

Trullas JC, Morales-Rull Jl and Formiga F. 2014. Diuretic therapy in acute heart failure. Med Clin. 42(1): 36-41 